Dana PERCEC

Faculty of Letters, History and Theology, West University of Timișoara

Timişoara, Romania

dana.percec@e-uvt.ro

\title{
SUBJECT OR OBJECT? THE ANTI-HERO OF THE ALLEGORY AND THE HERO OF THE ANTI-ALLEGORY
}

Recommended Citation: Percec, Dana. "Subject or Object? The Anti-Hero of the Allegory and the Hero of the Anti-Allegory." Metacritic Journal for Comparative Studies and Theory 7.1 (2021): https://doi.org/10.24193/mjcst.2021.11.11

\begin{abstract}
Referring to the British writers' prompt reaction to the Brexit crisis, in developing what has already come to be known as BrexLit, Robert Eaglestone remarks the "cultural and emotional landscapes" created by such literary responses, which attempt to "humanize" major political dilemmas. Ali Smith, commenting on the same speed of writing books "pressed against the contemporaneous," considers this as the result of history repeating itself with us failing to be aware of it, evidence of what we might call a community of unreliable remembers. The paper focuses on Ian McEwan's 2019 The Cockroach, a novella offering a reversed Kafkaesque metamorphosis, a pretext to satirize Brexit and to meditate on how the antiheroic character caught in this allegorical transformation devolves from subject into object. I argue that this process of objectification (using Martha Nussbaum's concept, derived from, but not limited to the feminist critique) contributes to the disembodiment and further relativization of memory.
\end{abstract}

Keywords: allegory, BrexLit, embodied memory, objectification, satire, unreliable rememberer.

\section{Introduction: The allegorical and apocalyptic mode}

Robert Eaglestone, editing a collection of critical essays dedicated to BrexLit, claims to have been surprised by the swiftness of the reaction of writers and intellectuals to discuss the results and effects of the 2016 referendum. He compares post-Brexit literature to the experiments of the war-time years, such as Huxley's or Orwell's: 
Books like Brave New World and Nineteen Eighty-Four were meant to alert us to the dangers of the authoritarian, totalitarian state, but it turns out they've been adopted as the playbook of both elected and unelected dictatorships across the globe. (...) We noted the similarities between these twentieth-century, ugly dystopian visions but didn't act with sufficient robustness to address the situation. There's a role for literature, so adept at humanizing big questions and creating emotional and cultural landscapes, in metaphorically poking us all in the ribs and urging us to start thinking critically and becoming politically active again (Eaglestone xvii-xviii).

This comparison implies that the relevance of literary texts often overlaps with the impact of historical and political events taking place at the same time, in the spirit which granted the success of the main claims advanced by cultural studies. Eaglestone's idea of literature "poking us all” is not a far cry from the initial hypotheses of cultural history, that great works of fiction pass the test of time when they address the workings of power.

Conversely, Rachel Cusk considers that writers and intellectuals didn't react fast enough to the Brexit phenomenon, the large amount of critical engagement with the topic took place after it and was rather pointless. In the collection of essays titled Coventry (2019), Cusk contrasts the post-Brexit deluge with the pre-Brexit silence, criticizing the intellectuals' inability to be proactive and their Phariseeism. Still, Eaglestone and Cusk would probably see eye to eye on the kind of "historical narrative (that) will eventually emerge from our current and future predicaments as exposed by Brexit" (Eaglestone xviii). This is usually problematic since the present has not yet given way to the future and the benefit (or lack thereof) of hindsight has not yet set in. Grand narratives are, more often than not, the privilege of the victors and/or of the majority, but, in the particular case of BrexLit, it is not immediately apparent if this "small" alternative narrative is necessarily the voice of the defeated and/or the minority.

A few common features can be identified, though, in these new, symbolic interpellations. On the one hand, there is the power of allegory - unfairly underrated in contemporary culture. Rachel Cusk begins the same collection of essays with "Driving as Metaphor," a meditation on how driving in and out a small English village can remind us all that the Brexit impasse is a result of Britain's lack of adjustment to practical, commonplace contemporary details. Driving through such old villages with narrow streets and bridges, scenic as it may be, "may present many obstacles to the 
flow of traffic" (Cusk 4). And then, "problems are constantly arising and though it could not be said to be the fault of these quaint places, they take on something of the character of an obstacle course" (5). Driving in this backwater immediately divides motorists into two irreconcilable sides. One side - "This being a backwater, it may be the case that people feel entitled to shed that burden (of driving carefully) here" because "in this remote place the distinction between private and public world is less clear" (5). The other side - "Others obey the rules of the road so deliberately and selfconsciously that their behaviour becomes distracting" (6).

The other allegory is Zadie Smith's, who, in her 2016 article "Fences: A Brexit Diary," watches a new fence being erected in her daughter's school yard and meditates that three decades after a great wall that separated Europe was pulled down, another one is being built somewhere else on the old continent. For an old and "pretty redbrick Victorian building" (Zadie Smith 1), this school, which has always sported its typical cast-iron railings, has now erected a tall wall, blocking the view of children playing. This new fence is doubled by an allegorical one: a very good school, which has served a multicultural community in the spirit of diversity for several generations, the place has now been downrated by the school inspection authority called Ofsted, which assessed it as not good enough, confining it to the "special measures" area.

Zadie Smith imagines four types of normal reactions to the Ofsted label: some parents would panic and withdraw their kids from this school; others might see what the school authority, focusing on statistics, "cannot humanly see" (1) and ignore the recommendation, valuing their own judgment more; others still "may not read well in English" or "have never heard of Ofsted" (1) and will carry on as usual; finally, there is a small category, like the writer herself, with "the advantage of local history" (1). She was a student at this school, and her brother taught there, so their personal experience with this place will always win over the apparently established, received view. The allegorical fence, therefore, is one separating between those who don't care or fail to be informed and those who know in an intrinsic manner. The received knowledge often dubbed as the memory of the community is a process of incorporating positive and negative recollections in the self-image, though the balance between the positive and negative aspects varies a lot in different historical periods. 
On the other hand, there is what Eaglestone calls the apocalyptic mode which most BrexLit writers so far seem to favour. The apocalypse is a hyperbole of the identity crisis which the referendum accelerated, overlapping with the (postpostmodern) cultural crisis. Eaglestone puts this overall pessimism down to a massive uncertainty: if this is not the end of history, what will come next in terms of personal as well as group experience? But to associate Britain in the twentieth/twenty-first century with the apocalypse is not a brand new story. When the Empire lost almost one million men in the Great War, there was talk of an apocalypse. When Britain emerged from World War II, barely alive and with the empire in shreds, there was, again, a sense of Götterdämmerung. Now, when the "small island" sense is no longer an abstraction or a joke, as it was when Bill Bryson wrote his funny travelogue (Bryson 2015), there is again talk of the apocalypse. Let us not forget, though, that the apocalyptic metaphor was often invoked in modern history. The first "joyful apocalypse" was, in the eyes of some historians, the beginning of the Industrial Revolution, which propelled Britain and other western countries into the modern age, with unprecedented speed and finality, but also with long-term negative consequences for the very fabric of the human condition, not to mention the pollution of the planet. This apocalypse was synonymous with a huge "technological risk" humanity took (Fressoz 2012), a gamble which didn't always turn out well. A more famous use of the syntagm belongs to Hermann Broch, the Austrian writer, who, together with other Viennese intellectuals during the fin-de-siècle period, regarded the irresponsibility of the multinational empires of Europe, waltzing or marching, elegantly yet inexorably, towards disintegration in the early twentieth century, as a "joyful apocalypse." (Schorske 5).

\section{The unreliable rememberer}

Referring to the important role played by memory in contemporary fiction, Aleida Assman comments that, nowadays, the unreliable narrator of modernist prose has been replaced by the unreliable rememberer (Introduction 170), as the embodied, individual, auto-biographical memory is negotiating its position with the historical memory. Arguing against Pierre Nora's widely embraced idea that "memory begins when the experience to which it refers has run its complete course," Assman suggests that the way in which memory is employed nowadays in the cultural as well as political discourse is the result of "the experience of hot pasts that will not fade away" (Assman 
2011, 4). Art and literature don't only immortalize events or persons through narratives and images, but they also contextualize, theorize, and criticize cultural memory, often more convincingly than the specialized scientific discourses of psychology or psychoanalysis. Again, unlike Pierre Nora, who deplores the swiftness with which the living, breathing present slips into an impersonal, historical past, with a destructive power against the fragile, ephemeral individual memory, Assman writes that embodied memory has been reclaimed by society: "we are currently facing, reconstructing and discussing new forms of memory that open up an access to the past that is distinct from and complementary to that which is provided by historical scholarship" (Assman 2011, 6). It is true that the memory which survives in minds and hearts is not an individual recollection but the cultural memory "underpinned by material carriers" (6), such as monuments, museums, memorials, archives and other written texts.

This surviving memory, which is an alternative to the grand narrative of history, mayeventually teach people the lesson that mainstream historical discourse has repeatedly failed to internalize, namely that there is nothing new under the sun, only patterns that are repeated cyclically, more like what one observes when studying the history of literature. This is what Ali Smith, Scottish author of the seasons' quartet that inaugurates BrexLit (Autumn 2016), argues in an interview about post-referendum British fiction:

Brexit's divisions? They aren't new. Brexit has just made them properly visible to us all. Is blatant political roguery new? Don't be daft, and neither is the handshake between propagandist persuasion and whatever the latest technologies happen to be. And one of the things that has been most interesting about writing books pressed so consciously against the contemporaneous is that nothing is really new in what's happening to us now. It's all there in classical myth, in Gilgamesh, in Homer; Dickens's Hard Times (Interview 1).

Smith then reaches a conclusion which looks very much like what Robert Eaglestone wrote about literature's capacity to capture and respond to events better than any other medium or form of discourse:

In the dark times, will there also be singing?” Brecht wrote in the 1930s. Yes, there will still be singing, about the dark times. [...] But beyond and above all this, in the 
end what survives of us are the stories of people's lives, how we live through the history we call the present, through the cycles of another year and another, renewing themselves and us again and again, bringing around the darker days, and the light (Interview 1).

Ali Smith's quick response to Brexit was regarded by some critics as "breathless automatic writing" (Preston 1), but it actually captures the phenomenon described by Aleida Assman very convincingly. The struggle between embodied memory and official historiography is reflected in the years that mark the lives of the two protagonists, Daniel Glück and Elisabeth Demand. Glück is 101 years old and he drifts more and more often back into a fuzzy past, while Elisabeth is constantly comparing the experiences of her life with the books she has read, a passion that has been kindled by Daniel when she was a little girl. Glück's life has traversed the turbulent century, from 1915 - the year when the initial optimism about the Great War sank in the mud of the trenches and large-scale massacre, the year of the Lusitania shipwreck and of the Gallipoli campaign- through 1943 - when French Jews (like him and his sister) were deported by the Nazis - through the 1960s - with the Beatlemania and Flower Power - into 2016 - the year of Prime Minister David Cameron's referendum and the beginning of the schism between Britain and Europe. Elisabeth's chronology is equally meaningful: she was born in 1984, the year of Orwell's fictional dystopia and of the real, Thatcherite dystopia, of the dramatic clashes between the government and the trade unions and of the great energy crisis. The private pasts of the characters, with the painful combination of nostalgia and guilt, overlap with the official, collective past of the nation. This correlation is reminiscent of Susan Sontag's idea, that there is no such thing as collective memory, just as there is no such thing as collective guilt; what lives with the individuals also dies with them and what is left behind is not remembered by a community, but stipulated: ideas and values are encapsulated in order to generate appropriate thoughts and feelings in the followers, a "hypothetical shared experience" of a "wegroup" (Sontag 6).

In their own way, other novels about the withdrawal provide a model for the unreliable rememberer's contemporary dilemmas. After Julian Barnes' 1998 novel England England, where the fun park upends monumental history, having already annihilated the embodied memory of the individuals who make up the English nation, 
Jonathan Coe's novel Middle England twenty years later (2018) relativizes the narrative of the Brexit to the maximum: what could be the objectivity, or, for that matter, the subjective reflection of the post-referendum years in the personal rhetoric of individuals from all walks of life and with conflicting political and personal agendas?

\section{Notes from Underground: Splendid isolation inside out}

Writing about the Great War, the war that was supposed to end all wars but managed only to end peace, as she puts it, Margaret Macmillan (36) locates the ultimate vulnerability of Britain in its obstinate desire to "stand alone." What politicians and diplomats called its "splendid isolation" in 1900 gave, from the beginning, only the false impression of an advantage - the non-intervention and the scheme to support, to its own geopolitical and economic advantage, the balance of power on the continent. It turned out very badly in the British geopolitical strategy during and after the Great War for the empire's colonial agenda. It turned out better during the Blitz crisis of World War II, but the loss of the empire was inevitable despite the country's reckless though - indeed - splendid courage and resistance.

The desideratum of isolation continued to haunt the political imagination into the twenty-first century, growing less and less splendid with every decade. Barnes' Anglia (1998) lives this anything but splendid isolation after the England England commercial experiment and Ian McEwan's cockroach turned prime minister (2019) leads Britain on the same path. A book "pressed so consciously against the contemporaneous," to quote Ali Smith again (Interview 1), is this novella written by one of the masters of satire and noir. McEwan's plotline seems quite simple: he suggests that the most absurd of the decade's political decisions could not have been concocted by a human mind, but by an insect, feeling and expressing itself in pheromone. Jim Sams is a cockroach who, one morning, wakes up in a human body, which, not accidentally, is that of the chief dweller of 10 Downing Street. Sams has a dream, shared only by the American President Archie Tupper, apparently also a once six-legged creature temporarily inhabiting the body of the most powerful man on the planet: Reversalism. This means the reversal of money flow so that the entire economy works anti-clockwise - people pay to do a job and are paid for shopping; the country pays for its exports and not for its imports, etc. 
But McEwan's idea is, in fact, not as simple as it looks. Critics were quick to salute the reference to Swift's satire, deploring, though, the fact that, while eighteenthcentury writers truly believed their caricature could change people, twenty-firstcentury authors know this mockery is only cold comfort (O'Toole 1). The futile disputes between Reversalists and Clockwisers - i.e., Leavers and Stayers - are indeed reminiscent of the partisans of the high-heelers and the low-heelers in Swift's fantasy travel. And clearly McEwan doesn't attempt his first intertextual exercise here. In 2016, he wrote Nutshell, a nod and a bow to Stephen Hawking's theories of the universe and to Shakespeare's Hamlet (the Prince of Denmark is, in 2016, a foetus who witnesses the adultery and murder from his mother's womb and avenges his father's death by being born, while the culprits are trying to run away from the police). But the subterranean quality of the 2019 novella brings it closer to Kafka's Metamorphosis not only because of the human-insect transformation. Gregor Samsa is the ultimate expression of the little man, a prototype so attractive to writers around the time of the two World Wars, when the heroic figures fade in the background and caricatural ordinariness is brought to the forefront. Samsa's insignificance is symbolized by his shrinking to the size of an insect and by his further emaciation to the point of selfannihilation.

The 2019 cockroach metamorphoses in reverse (like his economic project). He grows big enough to inhabit a fully grown human frame and to keep the entire nation, continent, and planet busy with his ideas of change. It is clear that change in this novella has a two-fold meaning: a magnified body coincides with a magnified (and megalomaniac) plan. However, the protagonist's name, so short and common for the ministerial position he occupies, his subterranean origins, habits, and tastes draw him closer to the antiheroic, than to the heroic (or villainous) paradigm. Jim Sam's notes from underground culminate with his musings that the cockroaches' Latin name, blattodea, explains it all, as "creatures that shun the light," that "understand and love the dark," a quality which has kept them in the close vicinity of the humans more than the latter species suspects, as "we have lived alongside the humans and have learned their particular interest for that darkness" (Cockroach 94). Sam's growth and magnitude of ambition is reversely proportional to his name and ignoble condition, and so is, in broader terms, the fate of the cockroaches, interlocked into that of the humans: "Where they have embraced poverty, filth, squalor, we have grown in strength" (Cockroach 95). 
The splendid isolation trope reaches momentum on the eve of R-Day. This is an (almost) iconoclastic reference to D-Day or V-Day, as is the comparison with Winston Churchill's evocation of the nation's "finest hour," here Sam's birthday, when Reversalism is unleashed into the world. The prime minister resolves that, since the country had stood alone before, during the Nazi terror, they can stand alone again: why bother with the Germans' automobiles now? Standing alone means standing at the beginning of a golden age, Sams declares in the House of Commons, and "the world will follow our shining example and every nation will reverse its money flow in order not to be left behind" (Cockroach 51). And when they prevail, a fellow cockroach praises the prime minister's victory thus:

Britain now stood alone. The people had spoken. The genius of our party leader had got them over the line. Their destiny was in their hands. Reversalism was delivered! No more dithering and delay! Britain stood alone! (Cockroach 93)

McEwan's irony is clear when the grandeur of this line of action is countered by the scene of the cabinet's return to the ditches, after the mission has been accomplished, when the "chancellor of the Duchy of Lancaster" is run down by a car. The other ministers hurry to grab him by his many legs and carry him into the gutter where they will feast on him during the celebratory dinner. Equally ironic is the dialogue imagined by McEwan between the German chancellor and Sams during the negotiations about Reversalism. Tired and confused, the European politician asks, rather rhetorically: "Warum?, which is rendered in English by the official EU translator: "Why, to what end, are you tearing your nation apart? Why are you inflicting these demands on your best friends and pretending we're your enemies?" The human trace of the prime minister would honour her with a complex answer: "Because that's what we believe in. Because that's what we said we'd do. Because that's what people said they wanted." But the cockroach hidden deep down in him answers just this: "Because" (Cockroach83).

If Reversalism is presented throughout this short book to be as absurd and pointless as Brexit itself, the closing lines of the novella provide another explanation for this conspiracy. The insects, a species millions of years senior to homo sapiens sapiens, refuse to be marginalized any more by the human parvenus. In order for the economy to be reversed, it first has to slow down and to halt, this being the 
cockroaches' chance to gain the upper hand by pushing homo britannicus back into the dark Middle Ages. "Hardship will harden the people of this great country. But that is no longer our concern" (Cockroach94) says Sams and closes the door behind him at Number Ten.

\section{A disembodied (or differently embodied) memory}

Writing about the process of objectification, Martha Nussbaum departs from the feminist view that assigns only a sexual connotation to it, treating it more as a "loose cluster term" (Nussbaum 258). The American philosopher lists seven possible stages in the process of objectification, which are reminiscent of the Foucauldian views about power exerted upon the individual unidirectionally, given the asymmetrical social structures. Literally, objectification means "treating as an object what is not an object" (257), hence Nussbaum's distinctions. Of the seven notions (instrumentality, denial of autonomy, inertness, fungibility, violability, ownership, and denial of subjectivity), many can be considered relevant to the discussion about metamorphosis and reversed metamorphosis, for the turning of subject into object and of object into subject. The denial of autonomy, with its treatment of the target "as lacking in self-determination" (257) is a starting point in both novellas, with ontological complications.

In Kafka's story, this process of objectification occurs gradually, as seen in the family's changing attitude towards the insect. In the early days, they suffer from shock - feeling, at the same time, that their financial stability is threatened - and try to help and hide the cockroach (they remove the furniture, leave bits of food on the floor for him to find, close the door so the tenants can't see him). Later, however, they grow tired of this drudgery and are increasingly aware of the grotesqueness and squalor of the situation, with the mother fainting in disgust when she sees the bug clinging to an elegant photo, and the father throwing apples to drive him away. When the cockroach dies, the family takes a ride on the tram, relieved to be finally able to make plans for the future and find a suitable husband for the sister, now that the source of embarrassment is gone. McEwan's story turns the process of objectification in reverse - like the mad financial scheme advanced by Sams - when the cockroaches remove the human outsiders from the group because they have opinions of their own. The foreign secretary's fate is sealed and his career is ruined callously when he turns out to be against the prime minister's Reversalism project. The leader of the opposition, Horace Crabbe, is presented as the least charismatic politician in history, someone 
with no sound alternative to offer the country, an old neo-Leninist, who can be ignored and even discarded with no remorse. If Sams is a caricature of Boris Johnson, and Crabbe, an equally grotesque bow to Jeremy Corbyn (whose position as leader of the opposition ended in 2020), the message is quite clear: few British politicians of the twentieth century and even fewer - if any - of the twenty-first can be considered charismatic and therefore not interchangeable ("fungible," to use Nussbaum's term). Of those, the ministers and politicians of the withdrawal will necessarily be forgotten by history. If they chose to "stand alone" against Europe, it is nobody's fault but theirs. The objectification of the humans, as well as of the insect protagonists, contributes to the disembodiment and further relativization of memory. Although the we-group made up of cockroaches seems to have a collective memory which runs millions of years back, far older than anything humans can remember, a memory they might rely on to gain an advantage over their human counterparts, this is only an illusion. What is stipulated, rather than remembered - to go back to Susan Sontag's essay - is only a hollow and vulnerable convention.

The arrival, in 10 Downing Street, of the cockroach, followed by his cabinet of other cockroaches, is presented by McEwan as the absurd explanation for an absurd situation. If no human being could create such a suicidal plan, then an insect might. However, Sams the bug does spare a few thoughts for the real prime minister. Where might he be? Would he be aware of what is going on in Britain during his absence? When the cockroaches slip through the open door and past the duty policeman, they are too preoccupied by the success of their mission and by the perils lying ahead (feet and cars during the afternoon rush hour) to notice "the little creature scurrying towards Number Ten to resume its life" (Cockroach 96). The insect minister is a "he," despite dreaming of dung and aspiring to enjoy a dead bluebottle fly with his afternoon tea, while the human politician is only an insignificant "it," whose embarrassment and awkwardness upon waiting in front of the Number Ten door is, in all ways, reminiscent of Gregor Samsa's state of mind after the metamorphosis. Rather than despair, for weeks, Kafka's clerk turned bug felt patiently self-conscious, facing his (its?) situation as a necessary ill that may, or may not, pass.

As for the situation the real prime minister will be faced with upon return, the author doesn't deem it necessary to probe into his human mind further. Instead, Sams the bug offers us a glimpse, dystopian as it may be. The cockroach species, in so many ways senior to the humans, has seen more of the physiological and moral cycle of life 
to know that "human desires are so often in contention with their intelligence," unlike the insects, "who are whole" (Cockroach 96). It took, indeed, a great deal of retrospective thought to (human) historians to conclude that balance is achieved with the help of a "great leveler."

In 2015, in Vienna, the first world congress on social inequality was organized, its outcome being a book about large-scale violence as a leveler, a paradox of history showing that this is a control and rebalance mechanism, which has worked again and again, through its four instruments, incidentally portrayed, with Biblical echoes, as the Four Horsemen (Scheidel 20). Apparently, society "never lent itself to peaceful equalization" (22), which means the faces of the Apocalypse were not only humanity's worst fears but also its buffers. Walter Scheidel concludes, perhaps a little too cynically, that history has shown that only the most violent shocks, which work "consistently" can "force down inequality" (23). So, the small apocalypse of Reversalism aka Brexit is summarized by the mastermind cockroach thus: "justice remains constant" (if the project may seem unfair to many, in its aftermath) because while "good-hearted people are bound to suffer, other decent, good-hearted, ordinary types will enjoy greater happiness. The net sum of universal wellbeing will not be reduced" (Cockroach 96).

\section{Conclusion}

How "dark" the cockroach conspiracy is and how "dark" the post-Reversalism age will be can be sufficiently estimated at the end of the novella. Insects seem to have understood humans better than humans have cared to understand insects, as paradoxical visceral beings, who, despite their erect position, which should have unequivocally and permanently favoured the light, have been drawn by darkness. This is a conclusion which could be deemed not dystopian, but rather "ustopian," a term used by Margaret Atwood to describe her post-apocalyptic novels (Atwood 14). Unlike a dystopia, which is only - and often exaggeratedly -bad, ustopia is a converging reality in which good and evil and perfection and chaos coexist as two sides of a coin. This view, shared to all appearances by McEwan, has something reassuring in it: while growing more aware of the fragility of our biological and civil condition, we are given a good tip, to slow down on the road towards future and take a more careful and informed look at the present. 


\section{References:}

Assman, Aleida. Cultural Memory and Western Civilization. Arts of Memory. Cambridge University Press, 2011.

---. Introduction to Cultural Studies. Schmidt, Erich Verlag, 2019.

Atwood, Margaret. Dire Cartographies: The Roads to Ustopia. Vintage, 2011.

Barnes, Julian. England England. Vintage, 2000 (1998).

Bryson, Bill. Notes from a Small Island. William Morrow Paperbacks, 2015.

Coe, Jonathan, Middle England. Penguin Books, 2018.

Cusk, Rachel, Coventry. Essays. Picador, 2019.

Eaglestone, Robert. Brexit and Literature: Critical and Cultural Responses. Routledge, 2018.

Fressoz, Jean-Baptiste. L'Apocalypse joyeuse, une histoire du risque technologique. Ed. Seuil, 2012.

Kafka, Franz. The Metamorphosis. SDE Classics, 2019 (1915).

Leith, Sam. “The Cockroach by Ian McEwan Review - Bug's Eye View of Brexit.” The Guardian, 26 Sept. 2019: 1.

MacMillan, Margaret. The War That Ended Peace. How Europe Abandoned Peace for the First World War. Profile Books, 2014.

McEwan, Ian. Nutshell. Vintage, 2016.

---. The Cockroach. Penguin Random House, 2019.

Nussbaum, Martha C. "Objectification.” Philosophy \& Public Affairs 24.4 (1995): 24991.

O’Toole, Fintan. “The Cockroach by Ian McEwan Review - A Brexit Farce with Legs.” The Guardian, 7 Oct.2019: 1.

Scheidel, Walter. The Great Leveler. Violence and the History of Inequality from the Stone Age to the Twenty First Century. Princeton University Press, 2017.

Schorske, Carle E. Viena fin-de-siècle. Politică şi cultură. Polirom, 1998.

Smith, Ali. Autumn. Penguin Books, 2016.

---. "Interview: I thought it would be about the seasons. Ali Smith on Writing Autumn." The Guardian, 21 Sept. 2019: 1.

Smith, Zadie. "Fences: A Brexit Diary.” The New York Times, 16 Aug. 2016: 1. Sontag, Susan. Regarding the Pain of Others. Picador, 2014. 